\title{
A Study on the Application of Food Sovereignty in International Law
}

\author{
Miguel Ángel Martín López \\ DOI: $10.21827 / 59 \mathrm{db67f29999e}$
}

\author{
Keywords \\ FOOD SOVEREIGNTY; RIGHT TO FOOD; RURAL WORLD; FOOD SECURITY; \\ SMALL-SCALE FARMERS
}

\begin{abstract}
The purpose of the present investigation will be to analyse Food Sovereignty in the light of international law. It constitutes at its heart a legal analysis of this concept, observing exactly how it has been developed until the present moment. By so doing, we will be capable of familiarising ourselves with its legal strengths and inconsistencies, along with showing what might be the way to take so that its proposals and aims obtain the greatest possible legal viability. The complete legal construction of Food Sovereignty has not been carried out. Moreover, one can say that the movement for the defence of Food Sovereignty has focused above all on constructing a discourse of a political nature. It is desired to achieve a ruling as detailed and broad as the program that defends Food Sovereignty, it is worthwhile to propose the creation of a branch within international law, which could be denoted as International Law for the Rural World. Especially as the preoccupation for rural territories is the element that is present in every aspect of this broad political program that defends Food Sovereignty.
\end{abstract}

\section{The Fundamental Conceptualisation: Food Sovereignty as an Essentially Political Program}

The championing of Food Sovereignty is gradually extending internationally and one can already discern a sizeable and plural global movement, fundamentally from the world of small-scale agriculture, which defends it. ${ }^{1}$ As a defining trait, Food Sovereignty arises as a grass-roots movement, inspired by a network of small-scale farming organisations and the rural world. Its objective is to achieve a wide-ranging transformation of the existing agricultural structures on a global level. ${ }^{2}$ It advocates for a complete program of measures

Professor of Public International Law, University Hispalense of Seville, Spain, the author can be contacted atmaml@us.es

1 In this sense the International Planning Committee for Food Sovereignty is very active. It is a network of global mobilisation and debate consisting of more than forty-five social movements and non governmental organisations that work with more than eight hundred organisations from around the world. It constitutes on a global level the only platform that functions as a repository of large organized bodies that represent hundreds of millions of food producers. It does not have a formal statute or legal identity. Its activity can be seen at: www.foodsovereignty.org.

2 In addition, the bibliography on food sovereignty is not very abundant, and even less so regarding legal aspects. It bears mentioning the following works: Windhfur, $M$ and Jonsen, J, "Food Sovereignty. Towards Democracy in Localised Food Systems" ITDG publishing, FIAN, (2005); La Souveraineté alimentaire: régards croisé, publication coordonée par Sophie Charlier et Gérard Warnotte, Presse Universitaires de Louvain, Louvain-La Neuve, (2007); Hauter, W, "The Limits of International Human Rights Law and the Food Sovereignty in Protecting People from further Trade Liberalisation under the Doha Negotiations", 40 Vanderbilt Journal of Transnational Law (2007) 107; Lee, R, "Food Security and Food Sovereignty", Center for rural economy, discusión paper series 11, (2007); Action 
and actions. Naturally, international law can provide quite a lot and it can be very useful in putting this program into practice. It is logical to think that this movement desires that its measures enter and become part of the international legal system so that that they are rules incorporated and fulfilled by States. Law is the most appropriate mechanism to satisfy their need to exist.

The complete legal construction of Food Sovereignty has not been carried out. Moreover, one can say that the movement for the defence of Food Sovereignty has focused above all on constructing a discourse of a political nature, ${ }^{3}$ without delving into a refined legal expression on these postulates. The logic governing the two is quite different. Political expression pursues the obtainment of support, it attempts to garner the cohesion of the greatest number of supporters, produce potent messages and shape and change reality. Political discourse also owes much to persuasion, psychology and even ideological characterisation. The studies and research that are being carried out on this material generally underscore this fact. For example, Madeleine Fairbairn, in an illustrative fashion, indicates that Food Sovereignty is being constructed with highly political language. ${ }^{4}$

Seen from the perspective of this political logic, one must recognise that it is succeeding, obtaining good results in this area. As such, there is a growing mobilisation and the coalescence of more support. Its postulates are beginning to expand and continue to gain attraction. They are even starting to be accepted by some States. The example of Ecuador, in its recent constitution, can be given; Venezuela, with its July 2008 adoption of the decree on Food Sovereignty ${ }^{5}$ Paraguay, which has included these postulates in the recent National Plan for Food Sovereignty and Security and Nutrition for Paraguay, Planal; ${ }^{6}$ or Nepal, where the government has already committed to incorporating Food Sovereignty as a fundamental right of its people into the next constitutional reform. ${ }^{7}$

Nevertheless, the legal articulation of this discourse, through legal techniques and their demands for precision and detail, is also necessary. However, as of now, it can be said that this has yet to be done and that this process can only be found in its earliest stages. That is also generally recognised in the works and research on this issue.

Group on Erosion, Technology and Concentration(ETC group), Food's Failed State: Paris's Hot Cuisine. Food Sovereignty à la Carte?, January 2008; Haugen, HM, "Food Sovereignty: an Appropriate Approach to Ensure the Right to Food?", 78 Nordic Journal of International Law (2009) 263-292; Food Sovereignty. Reconnecting Food, Nature and Community, edited by Wittmann, H, Desmarais, AA, and Wiebe, N, ed Fenwood publishing and Pambazuka Press, Cape Town, Dakar, Nairobi and Oxford, 2010; Ortega Cerdi, $\mathrm{M}$ and Rivera-Ferre, M, "Indicadores internacionales de Soberania Alimentaria. Nuevas herramientas para una nueva agricultura" Revista Iberoamericana de Economia Ecológica 14 (2010) 53-77; Schanbacher, WD, The Politics of Food. The Global Conflict between Food Security and Food Sovereignty (Praeger, 2010).

3 This political connotation is explicit, for example, in the declaration from the Committee for Food Sovereignty in Latin America and the Caribbean, Santiago de Chile August 18th, 2009.

4 Fairbairn, M, "Framing resistance. International food regimes and the roots of food sovereignty, Food Sovereignty" in Desmarais, A, Wittman, $\mathrm{H}$ and Wiebe, N, eds, Food Sovereignty: Reconnecting Food, Nature and Community (Fernwood, 2010).

5 Gaceta Oficial, 5891, (31 July 2008), Ley de Seguridad y Soberanía Agroalimentaria.

6 It was made by the government of this country with the support of the FAO and approved in June 2009. In other Latin American countries the issue is being discussed, as is the case with Panama or Bolivia, where there is a desire to pave the way for a law in that regard.

7 It is already found expressed in its interim constitution of 2007, specifically in the third paragraph of Article 18. 
As has been said, Food Sovereignty arises as a grass-roots movement, generated by a network of small-scale farmer organisations, and on account of that they can be considered guilty of a certain measure of ignorance regarding the procedures and details of international law. They lack the technical legal knowledge but, on the contrary, it is undeniably an original initiative and they can provide a kind of fresh air that is replete with a transformative strength desirous of change in the international structures and the rules of this international legal order.

The proposal of this current research is going to be, therefore, to analyse Food Sovereignty in the light of international law. This paper aims to conduct a legal analysis of this concept, observing just how it has developed until the present. By doing so, one will be able to understand its strengths and legal inconsistencies as well as be able to show which path should be taken so that its proposals and intentions obtain the greatest possible legal viability.

\section{The Non-existence of an Accepted and Precise Concept of Food Sovereignty}

The start of an investigation of this type must be centred on determining with precision and clarity the concept of Food Sovereignty. This first step is essential in order to be able to subsequently extract the legal consequences. Indeed, currently there is no single universally accepted, well-delineated and well-defined concept. This lack of a universal definition appears to constitute one of the main criticisms with respect to Food Sovereignty. This is how, for example, in a most illustrative way, Great Britain went on the record in its reservations towards the approval of the International Assessment of Agricultural Knowledge, Science and Technology for Development (IAASTD). ${ }^{8}$ It expressly indicated that there is no international definition of Food Sovereignty.

In addition to the absence of an accepted concept, the existing definitions also provide considerably varied content. They include many different components within the concept. This aspect also is a source of easy criticism and it acts as a damper on the greater expansion of the very concept of Food Sovereignty itself. In this sense it is worth drawing attention to the work published in the Nordic Journal of International Law by Hans Morten Haugen, who makes manifest that its content is always changing and is being modified, at times due to diverse pressures, and to the concept's detriment that triggers the loss of considerable consistency. ${ }^{9}$

Michael Windfur, another important author, also underscores that Food Sovereignty is still not sufficiently defined and established as a conceptual body. ${ }^{10}$ Equally, Professor William D. Schanbacher, another expert on the subject, also indicates

8 It is common knowledge that this report from April 15, 2008 emerged from a group of organisations from the United Nations and individuals representing governments, civil society, the private sector and scientific institutions who selected more than four hundred scientists from diverse sectors from around the world, working for three years on what must be the role of agriculture in general knowledge, science and technology. The result was released under the auspices by all the agencies of the United Nations, the World Bank, a large number of non-governmental organisations and representatives of more than sixty governments, although some have expressed reticence.

9 Haugen, HM, supra nt 2, 270.

10 Windhfur, M, Jonson, J, supra nt 2, 13. 
expressly that with regard to human rights, the concept of Food Sovereignty is still vague, with there being a need to continue elaborating this process. ${ }^{11}$

Therefore, it is logical to think that if there is no one accepted definition, there cannot be clarity either in the legal instruments that are required to develop and make the concept operative on national and international levels. A consensus would have to be reached concerning the borders and limits of the concept, about what is included and what is left out, given that the variety, as has been mentioned earlier, is wide-ranging when it comes to the definitions of Food Sovereignty.

Thus, it has been said that Food Sovereignty has, in terms of demands, access to natural and productive resources on the part of the communities, the desire to do away with commercial liberalisation in agrarian matters, the need to adopt agro-ecology and its practices or to reject the use of genetically modified crops. This field grows even larger with other areas like welcoming agrarian reforms, the protection of small-scale farmers and their rights, respecting vegetable genetic resources and limiting their appropriation through intellectual property rights.

On a separate front, there is also a defence of the notion that Food Sovereignty must necessarily not only include democracy, the participation of communities in the decision making processes and their control of natural resources, but also gender equality and fomenting the productive role of female small-scale farmers. In addition, it must not be understood that all these aforementioned characteristics completely consume the content of Food Sovereignty. It must not be understood as a numerus clausus. Rather it seems that there exists a greater basis to comprehend that that which is desired is that it possesses a kind of open content, which gradually continues to expand.

As a whole, it must be recognised that some effort has started to be made to synthesise Food Sovereignty better and to reduce its concepts to a few essential points. One can highlight in this sense the labor performed by Via Campesina, which, in various documents and decisions, manages to summarise the content of Food Sovereignty in seven major principles. Concretely, these are the principles: the right to food as a basic human right, agrarian reform, the protection of natural resources, the reorganisation of the commerce of agricultural products, ending the global spread of hunger, social peace, and democratic control.

Nevertheless, there is still room for improvement when it comes to making a greater effort to synthesise ideas, like what was carried out by the Forum on Food Sovereignty in 2002. In this forum it was possible to boil down the concept to four key principles. These principles are the right to food, access to productive resources, the promotion of agro-ecological production, and attention to problems in commerce that stem from the fact that local markets must receive priority status.

Separately, each one of these principles brings with it a whole host of implications. Putting a principle into practice cannot happen just by reducing it to singular law nor to one general principle of international law. It rather requires the adoption of many complementary rules and of development. Honing in, it would deal with engaging in an entire legal project. What is more, the most surprising thing is that one of these principles is an existing right in the international legal order, the right to

11 Schanbacher, supra nt 2, 107; Windfhur, M, supra nt 2, 37 also points out, "food sovereignty is not yet sufficiently defined and established as a conceptual framework to be able to decide precisely which legal instruments and infrastructure will be required to support it at national and international levels. The use of terminology and definitions, particularly the rights based language needs to be more precise." 
food, although its defenders have not gotten around to explaining the relation between the two.

Consequently, it is an unfinished concept that lacks acceptance. Therefore, there are no minimum guarantees for legal recognition for Food Sovereignty and it seems that putting it into practice will still require a whole battery of rules, without which it cannot be reduced to a general principle or a single rule. As a consequence, it is necessary to delve deeper and to carry out a greater legal elaboration of Food Sovereignty.

\section{Analysis of Food Sovereignty as a Right Belonging to the State}

In spite of the previous criticism, one must not reach the conclusion that the lack of a clear concept constitutes an intractable apory for the legal development of Food Sovereignty. There is, without a doubt, space to open new pathways and so one will be able to centre the analysis on seeing who can emerge as the holders of a right to Food Sovereignty. On this question there are also differences, and diverse holders have been postulated, which is the reason why it may be interesting to study who they can be and how far their rights go as holders. That would help shed valuable light upon the legal classification of Food Sovereignty.

Without a doubt, the first potential holder of this sovereignty that comes to mind is the State. It is logical to advocate for Food Sovereignty to be a right that corresponds to each State. One can even go so far as to think that Food Sovereignty can only be a part of the concept, more general in nature, of course, of State sovereignty.

This, as one knows, is an essential attribute of the State and translates into a series of powers and competences over what occurs on its territory. These competences, moreover, are protected by international law and are recognised by all the States in the world. In this order, the validity of the principle of sovereign equality of the States, particularly in the article 2.1 of the Charter of the United Nations, is well recognised. In a similar sense, the important Resolution 2625 (XXV) of Principles of International Law underpins the relations of friendship and of cooperation among the States and also expressly orders that each State enjoys the inherent rights to unhindered sovereignty. Naturally, it is within reason to think that these powers that sovereignty gives can provide the State with the capacity to control all that is relative to food in the interior of its country.

This is defended by numerous positions and also by the movement for the defence of Food Sovereignty. This movement has, in numerous texts and documents, alleged that the State must have full dominion to control and regulate all pertaining to the production and consumption of food in its interior. It must be a right that belongs to the State. Via Campesina, for example, has expressly defended in various publications the position that Food Sovereignty must be centred on the right of the State to maintain and develop its very own capacity to produce basic foodstuffs, respecting cultural and productive diversity.

In a similar vein, one can also find the influential and aforementioned report from the International Assessment of Agriculture, Science, Knowledge and Technology of Development (IAAST). This advocates that what is most important in Food Sovereignty must be the capacity of the State to determine its inherent agricultural and food policies.

In the face of these positions, the question becomes mandatory: Do states possess a right to control alimentation in their interior and to set their own food policies? It must be ruled that, in accordance with current international law, the answer is affirmative. The truth is that State sovereignty as currently conceived by international law, gives power to 
the State to perform such control and nothing legally obstructs it from possessing the capacity to define said agrarian and agricultural policies.

However, is the movement for the defence of Food Sovereignty fully satisfied with this situation? One supposes that the answer is negative, given that it is simply a formal recognition. The State can have the right, although it is not capable to put into effect such policies.

One must think that, at the deepest level, the demand which this group pursues is that sovereignty in these areas be not just formal, but real as well. It is of interest to make, therefore, a normative proposal that gives efficacy to the State's capacity for control.

The claim for authority is comprehensible if one keeps in mind that in the last few decades States' margin for action to support each respective system of agricultural production and their small-scale farmers has been reduced, particularly in the countries of the south. This is due fundamentally to the implementation of the widely known plans for structural adjustment policies that international financial organizations such as the International Monetary Fund and the World Bank have advocated as pre-conditions to receiving their aid and loans. The aforementioned organizations were especially prejudicial towards small-scale farmers denying them services, credit or any other kind of support. When public intervention is undercut it is usually made manifest by all the defenders of Food Sovereignty.

These actions also demonstrate that the margin for state action has also been diminished due to the system and legal regime of international agricultural commerce that has been in force. ${ }^{12}$ It has been abundantly demonstrated that high subsidies for agrarian production in developed countries, its subsidies for exports, and the dumping of these products has considerably damaged the internal possibilities for production of many countries. Likewise, it also has been highlighted that the States end up subordinated to agro-industries and big multi-national firms in the sector that take full advantage of the lack of legal regulation. This considerably affects small-scale agriculturalists negatively in under-developed countries that compete at a disadvantage. In general, it appears that this tendency is present in many sectors. That is essentially how the aforementioned Micheal Windfur describes it. He literally points out that today society stands before a loss of authority on part of governments to regulate important areas of national policy such as commerce, biodiversity and land policy. ${ }^{13}$ The political space for the State to make its very own decisions is being reduced considerably. Consequently, given the current state of affairs, one can understand that an imperative respect is desired for this sovereignty on the part of other States, international society, and other subjects of this legal system such as international organizations and multinational businesses.

To give legal form to this aspiration, we deem it a case in which it is desirable to endow this aspect of food production in the interior of the country with an inviolable character. It is the greatest protection that sovereignty can bestow and it would be the

12 Carlson, J, "Hunger, Agricultural Trade Liberalization and Soft International Law: Addressing the Legal Dimension of a Political Problem", 70 Iowa Law Review (1985) 1186.; Madeley, J, Hungry for Trade (London, Zed books, 2000); Ritchie, M, and Dawkins, K, "WTO Food and Agriculture Rules: Sustainable Agriculture and the Human Right to Food", 9 Minnesota Journal of Global Trade (2000) 9; Konandreas, P and Sharma, R, "Net Food-importing Developing Countries: Role and Perspectives" in Bilal, S and Pezaros, P, eds, Agricultural Trade and the Millenium WTO Round (Kluwer Law International, The Hague, 2001), 251.

13 Windhfur, M, Jansen, J, supra nt 2. 
same that states possess with respect to their territory. Resolution 2625 (XXV), alluded to earlier, states quite clearly that territorial integrity and the State's political independence are unassailable. As Judge Jules Basdevant, a classic advocate, has already said, territorial sovereignty is the most important and genuine manifestation of that condition.

If the production of food is also considered to be incontestable, one must understand that any attack on or disruption of the capacity to produce food in the interior of each State would be contrary to international law. This recognition necessarily implies that the legal consequences that come with it must be accepted. These legal consequences would be the annulment of numerous rules that oppose this inviolability. Implicitly, in a certain sense, those groups that defend Food Sovereignty and have advocated the abolishment of the rules that are in opposition to this end know this well, particularly the rules of the World Trade Organization, as well as the advising on agrarian matters, on the part of international financial institutions. The well-known Declaration of Nyéléni, February $27^{\text {th }}, 2007$, goes well beyond that and includes a wide and extensive relation of contestations against the existing international order. In a very expressive way it states "What we are fighting against": the domination of our food and food producing systems by corporations, the privatisation and commodification of food, imperialism, neoliberalism, neo-colonialism and patriarchy, etc.

Consequently, the legal essence of Food Sovereignty, as a State's right, must be to impede the actions and omissions that could destroy the capacity to produce food in its interior. It ought to be a general law that could cover the multiple and varied instances capable of producing the aforementioned result.

Without a doubt, the area where one can expect a greater application is in international commerce. Here, the national productive capacity could end up very compromised. We have already indicated the concurrence of dumping, export subsidies and other similar measures that produce and, in fact, have produced said result. Food sovereignty, exactly as we have visualised it, ought to exert itself so that this does not occur, changing the current state of affairs.

Thus, for this law to be effective, it must be given a figurative seat at the negotiations under way, ${ }^{14}$ with a modification of the commercial agricultural regime, introducing protective mechanisms for local production. Via Campesina was already conscious of this in 2001, when it defended the notion that Food Sovereignty must imply the right of all countries to protect their internal markets, putting limits on any and all imports that may damage said sovereignty. This ought not to be a new and different right but rather a consequence of Food Sovereignty as an inviolable right belonging to the State.

Above all, the clearest attack on this capacity for production is the existence itself in the international order of the condition of States that are net importers of food. More than forty States in the international community fall into this category, which is recognized by the World Trade Organization. ${ }^{15}$ These are states that are food dependent on international markets and whose own systems possess a limited production capacity, in many cases because they have not been sufficiently developed and because they do not receive incentives for it. Here as well, the right of the State to Food Sovereignty must

14 There is currently a text under negotiation called Revised Draft Modalities for Agriculture, TN/AG/W/4/Rev. 4, WTO, Committee on Agriculture, Special Session, 6 December 2008.

15 Decision on Measures Concerning the Possible Negative Effects of the Reform Programme on Least Developed and Net Food-Importing Developing Countries, Uruguay Round Agreement. 
include the elimination, at least gradually, of this statute of net food importing States. The rule, without a doubt, can be applied in many more areas. For example, land that is removed via acquisition from useful agricultural production for other uses, the conditions of the multi-national companies that destroy agricultural biodiversity etc. One would have to analyse the casuistry and draw up indictments in the concrete cases so as to get to the bottom of whether there is really significant damage to its own capacity for food production in its interior.

\section{Perspective Regarding Food Sovereignty as a Right that Belongs to Peoples}

In the previous epigraph we have approached Food Sovereignty as a right of the State. Moreover, it also has been defended that the entitlement belongs to peoples, there is even a clear preference in granting them this entitlement before governments as can be seen in multiple documents and declarations from the supports of said Food Sovereignty.

Thus, resorting to peoples is extremely important. The well-known and cited Declaration of Nyéléni corroborates it in that way, it itself going to the point to affirm expressly that Food Sovereignty is possible only if there is sovereignty on the part of the people. That being the case, various and questions necessarily arise: Will it be a State's right or a people's right? Is there the possibility that both can be holders concurrently? Is it possible to share this entitlement?

Firstly, one must proceed from the basis that international law allows for peoples to be holders of rights. There is no legal obstacle to this possibility. A quite clear illustrative example is the existence of the right to self-determination of all peoples as stated in Article 1 of the United Nation's International Covenant on Civil and Political Rights. It is a right directed at them and in force in this legal order.

Furthermore, it is certain that in this case the entity of the people disappears once the State is constituted. The latter becomes its one and only legitimate representative, becoming enveloped exclusively as a part of this State. On this basis some doctrine defends the notion that the people cannot have their own legal subjectivity when there is a State. Nevertheless, this doctrine is being widely outstripped and a large part of the authors already comprehend that there can be rights of a people in the current international order even though a State has been constituted. An example of that is the permanent sovereignty over natural resources. The international texts that cover this rule make express mention of peoples. ${ }^{16}$

In these suppositions a double entitlement would be given to cover the same right. It belongs simultaneously to the State as well as to the people. In an abstract sense, there is no reason why it should make any legal difference that a right be shared. Ultimately, every people's right must also belong to the State, given that the latter represents the former. Therefore, that which is of interest is seeing what added value is there when a right is expressly conceded to the people.

One may believe that the answer is easy and that it possesses a very clear legal logic. Giving rights to peoples in international law functions as a precaution in the face of the States' actions, or, better said, of their governments' actions. James Crawford,

16 UN General Assembly, Permanent Sovereignty over Natural Resources, 14 December 1962, GA/Res/1803 (XVII). 
professor at Cambridge University, has already described this idea as well. In his words, "if the expression peoples' rights has any independent meaning it is because they confer rights to peoples against their own governments."17 This is necessary on many occasions, given that the government can be less than diligent in its defence of these rights and can even renounce or abrogate them, which is prejudicial to the interests of the people. In practice many allegations in this sense have been observed. These precautions are, without a doubt, necessary in the field of Food Sovereignty. One would manage to provide a greater legal guarantee and it implies a kind of reinforcement so that the government is active in the protection of its principles and values. There is no room for doubt that by so doing it will end up making the right stronger. In addition, one must presume that the movement for the defence of Food Sovereignty wants it that way and, thus, this proposed set of rules must be regarded in a positive light.

Lastly, it is of importance to plainly state that in practice one encounters the use of terms of a most varied nature to denote this people's right. One can read in the texts and international documents of people's rights to nutritious food, of the right to healthly, culturally appropriate and organically produced foods, of the people's right to access and control of natural food resources, of the right to decide about food and productive systems - there is simply a wide variety of them. Nevertheless, there is a denotation that prevails over the rest and that gets repeated more. That is the right of peoples to feed themselves. This denotation has, certainly, a considerable expressive force, considering that it is capable of accurately describing the essence of Food Sovereignty. In addition, it is a very wide and general legal concept within which the other denotations can be understood, such as the right to decide on one's politics or the access to natural resources. Moreover, it is also more significant. For example, it makes very clear that the aforementioned condition of net food importer State is contrary to this right. Moreover, it is a concept with the greatest baggage associated with it in the international community. Already in 1996, the Frenchman Bertrand Hervieu utilised it as the title of his pioneering book published by the publisher Flammarion. ${ }^{18}$

Therefore, for the purpose of effectively channeling legally Food Sovereignty as a people's right it will be necessary to avoid the aforementioned plurality of terms and ways to which it has been referred. It will have to rest exclusively upon the concept of a right to feed oneself when we refer to the people's right. There must be a terminology accepted and recognised by everyone. With this condition satisfied, we will be able to provide with greater strength that larger guarantee that we have mentioned previously as something typical of rights of this type.

\section{The Local Communities as Owners of Food Sovereignty}

The list of possible owners of Food Sovereignty does not end with States and peoples. The analysis of the documents and texts that advocate it is capable of expanding even more. Above all, one repeatedly hears the need to concede this right to local communities composed of indigenous, small-scale farmers. In fact, in several of the definitions of the concept of Food Sovereignty one refers to these local communities simultaneously and at the same level as the State and the people. It becomes patently clear in these postulates

17 Crawford, J, "The Rights of Peoples: Peoples or Governments?", 9 Bulletin of Australian Society of Legal Philosophy (1985) 136.

18 Hervieu, B, Du droit des peuples à se nourrir eux-mêmes (Flammarion, 1996). 
that the movements that defend Food Sovereignty grant great importance to this expansion.

Additionally, in these documents it is considered that the local communities must receive a great variety of rights. The local communities must possess the right to produce locally and sustainably, and there must also be the right to control the existing natural resources in their territory as well as the right to access them. Furthermore, they ought to have a guarantee for the protection of the biodiversity in their territory, for their traditional knowledge, and for their local environment and ecosystem. They also must have protected their right to not be submitted to the dictates of the multinationals in the sector. These are all linked to Food Sovereignty although they seem to be conceived as autonomous rights.

There is no doubt that the legal questions, raised by this proposal for the expansion of the ownership of Food Sovereignty to local communities, are of interest. One must ask a series of questions: Is it viable to grant this expansion? Is there room for it in international law? Up to what point will the content of the rights that can be granted to said local communities go?

As a starting point, one must keep in mind that the reference to local communities is already present in multiple resolutions and texts of an international nature, particularly in environmental negotiations. ${ }^{19}$ Its use in practice is widely extended internationally, for example, the recent Rio +20 Summit. $^{20}$ One can even find some assumption of its acceptance in a text of obligatory normative nature, such as the International Treaty on Plant Genetic Resources for Food and Agriculture, backed by the conference of the FAO and adopted in November 2001 (Resolution 3/2001). This treaty, concretely in its fifth article, refers to local communities and urges the states to support their efforts. ${ }^{21}$ These antecedents already open the door so that, at least in theory, a legal recognition of the role of local communities in the matter of Food Sovereignty becomes viable.

However, what is interesting is, without a doubt, to posit why it is desired to grant this recognition. It is easy to deduce that the basis is the same that we mentioned before in the case of the people. It is also desirable to establish some form of precaution when dealing with the government so that it does not deviate from the obligations arising from Food Sovereignty. In this case, this is a precaution with minimal reach. One desires to assist in its application to a given territory, this is the domain of a local community that is ultimately directly affected. It would, therefore, be the legal guarantee of greatest precision in the application of Food Sovereignty.

This being the case, the next question must be framed so as to determine what the content is and how does one specify the obligations of Food Sovereignty on a local level. In this sense, we can discern that the normative proposal must deem contrary to law any

19 Fach, E, Legal empowerment of local communities: a role for international environmental law? 10, at <scps.nyu.edu/export/sites/scps/pdf/global-affairs/estelle-fach.pdf> (accessed 12 November 2016); Maggio, GF, "Recognizing the vital role of local communities in international legal instruments for conserving biodiversity", 16 UCLA Journal of Environmental Law and Policy (1997-98) 179.

20 Report of the United Nations Conference on sustainable development, Rio de Janeiro Brasil, 2022 June 2012, A/CONF. 216/XX, 88.

21 Art. 5.1 Each Contracting Party shall, subject to national legislation, and in cooperation with other Contracting Parties where appropriate, promote an integrated approach to the exploration, conservation and sustainable use of plant genetic resources for food and agriculture and shall in particular, as appropriate: (c) Promote or support, as appropriate, farmers and local communities' efforts to manage and conserve on-farm their plant genetic resources for food and agriculture. 
means that annul the capacity to produce food for the inhabitants of a concrete territory. The causes that can be provided for such a situation will probably be most varied in nature, for example, property transfers or company projects.

Naturally, it will be necessary to make efforts to lay down this law in a more detailed manner. In addition, it is believed, without a doubt, that this task will bear more fruit than to advocate the creation of a multitude of autonomous subjective rights for local communities, such as the aforementioned ones. The process of taking effect and acceptance of all these rights by international law will be much slower. It is also certain that there are certain rights that seem too abstract and it is difficult to visualize their concrete application. On the other hand, it also would be interesting to propose that, with the objective of putting into practice this Food Sovereignty in specific local areas, prior, free and informed consent would be required from the local communities affected by any given measure or action that could have a negative impact on said sovereignty, as was indicated previously. This rule of prior, free and informed consent has been making inroads in the international order in other areas. ${ }^{22}$ One must defend the investment in land acquisitions such as for indigenous peoples or for development projects. Prior, free, informed consent, thus, has a certain track record and acceptance in the international order, which could facilitate its rapid acceptance in the context of Food Sovereignty. It can, therefore, be proposed that the rule of prior, free and informed consent should be a formal indispensable requisite in order to introduce Food Sovereignty in concrete territories, demanding it before any action that could limit the capacity to produce food in the confines of a local community.

\section{The Relationship Between Food Sovereignty and the Human Right to Food}

It is within the realm of possibility to imagine that the ownership of Food Sovereignty may be expanded. Thus, breaking free from the postulates of the movement for the defence of this Sovereignty one could conceive it as an individual human right. If that is the case, it could follow that the human person may be direct owner of this title, as well. ${ }^{23}$ This conception of Food Sovereignty as an individual right, belonging to each person, was added expressly to the October 2004 revision of the concept of said

22 The Inter-American Court of Human Rights has indicated that "in the case of larger-scale developments that could impact the survival of a people, the State has the duty not only to consult, but also to obtain free, prior and informed consent" Saramaka peoples v. Suriname, judgment Inter Am Ct H. R. (ser c) $n^{\circ} 172$, nov. 28, 2007 (par. 134), 64. See Ward, T "The right to free, prior, and informed consent: indigenous peoples participations rights within international law", Northwestern Journal of International Human Rights (2011), p. 54 ss. Free prior informed consent and beyond. The experience of Ifad, International Workshop on methodologies regarding free and informed consent and indigenous peoples, Department pf Economic and social affairs, PFII/2005/WS.2/10. Firestone. Laurel, A,: "You say yes, I say no. Defining community prior informed consent under the convention on biological diversity", 16 Georgetown International Environmental Law review (2004) 181; Brant, M,: "The community referendum: participatory democracy and the right to free, prior and informed consent to development", 27 Berkeley Journal of International Law and social affairs (2009) 570.

23

Debuyst, F, also defends the notion that this content is the capacity of the States to insure food sovereignty for all, see Debuyst, F,: Des options pour la sécurité alimentaire face aux contraintes d'une societé de marché, La Souverainté alimentaire, supra nt 3, 194. 
sovereignty done by the Committee of International Planning for NGOs. This proposal is also included in the Declaration of Nyéléni, one of the most prominent texts of said movement, which arose from the forum, held in Selingue (Mali) on February 2007. This declaration expressly states that one of its objectives is to fight so that Food Sovereignty is considered a basic human right. Moreover, the declaration indicates that this right must be recognized by communities, peoples, States and international institutions. It is accepted, therefore, as an essential postulate. This extension of Food Sovereignty to every single individual opens the door to a volume of content that is excessively wide.

The doubts about these affirmations are logical and evident. For example, is it legally viable for such a right to be recognized and admitted into international law? We consider that this question must be answered in the negative. The content that is required of Food Sovereignty, as has been observed, lends itself very little when it comes to functioning as a human right, belonging to each person individually. A more precise individualization appears to be impossible. It is commonly believed that it cannot even be conceptualised as a right of a collective nature, enjoyed equally dependent upon an undetermined relation among persons. Consequently, it is of the utmost difficulty to conceive of Food Sovereignty as a human right belonging to each person. A proposal in this sense is scarcely viable and sustainable.

Despite this conclusion, the relation between Food Sovereignty and human rights must not be understood as being non-existent. The two are not, without a doubt, totally separate and isolated fields. It is interesting to study this relation and to see what legal consequences can be derived.

In this sense, naturally, what attracts one's attention is the interrelation between the right to food and Food Sovereignty. What exactly is the link between the right to food and Food Sovereignty? The question is of interest and there is little room for doubt that said right is, by its own nature, the one with which Food Sovereignty has most in common. The truth is that up to the present date not very much light has been shed on this question. There is no clear and accepted response.

The most widely accepted idea is that there is no connection between the two concepts. Considerable doctrine deems Food Sovereignty a concept distant from reality. It has no validity in the international legal order and the most probable scenario is that it will not manage to ever do so. On account of that, it is understood that the efforts in the fight against hunger must be focused on the right to food. A greater development and strengthening of this right must be achieved. As is known, this idea was already expressed in the Universal Declaration of Human Rights (Art. 25) and the International Covenant on Economic, Social and Cultural Rights (Art. 11). ${ }^{24}$ The FAO has made

24 Article 11 states: "1. The States Parties to the present Covenant recognize the right of everyone to an adequate standard of living for himself and his family, including adequate food, clothing and housing, and to the continuous improvement of living conditions. The States Parties will take appropriate steps to ensure the realization of this right, recognizing to this effect the essential importance of international co-operation based on free consent.

2. The States Parties to the present Covenant, recognizing the fundamental right of everyone to be free from hunger, shall take, individually and through international co-operation, the measures, including specific programmes, which are needed:

(a) To improve methods of production, conservation and distribution of food by making full use of technical and scientific knowledge, by disseminating knowledge of the principles of nutrition and by developing or reforming agrarian systems in such a way as to achieve the most efficient development and utilization of natural resources; 
efforts in advancing the right to food, adopting in the bosom itself of the organization a decade ago the Voluntary Guidelines for the progressive development of the right to food, ${ }^{25}$ which develop in the widest and most detailed manner the content of this right. Nevertheless, they remain non-binding guidelines. The FAO and other institutions of the United Nations fundamentally operate on the same lines. Indeed, in their official texts and declarations one can really see how they do the utmost to avoid the use of the term Food Sovereignty. They do not mention it.

Conversely, the texts of the defenders of Food Sovereignty have gone to the point, as was indicated before, that the right to food is one of the essential components of their postulates. It is granted maximum importance. Although afterwards neither development nor systemization of how the two concepts are interrelated can be found.

Along the same lines, support can also stem from one of the former Special Rapporteurs of the United Nations on the Right to Food, professor Jean Ziegler, who defends this posture, trusting considerably in the contributions that Food Sovereignty could give to the right to food. He expressly affirmed in one of his reports that Food Sovereignty is the best mechanism to make the right to food possible. ${ }^{26}$ Nevertheless, his reports failed to develop in detail how this interrelation is produced.

Consequently, it would be useful if it is investigated what the connection between both concepts is, preferably with useful and operative conclusions. Certainly, it is believed to be ideal if both concepts were to converge instead of functioning separately. This is in essence what is happening, since, a large part of the defenders of Food Sovereignty consider it important to develop and strengthen this sovereignty instead of the right to food. For many of the defenders, this right is itself limited, not very effective and scarcely transformative. One can begin to see that the best way to achieve this convergence is to advocate that postulates from Food Sovereignty enter into the content of the right to food. Of course, it would be interesting if the obligations that arise from this right were widened and enriched by including what Food Sovereignty defends and that it constitutes part of the content of food sovereignty. What is more, without a doubt, this route is more efficient in making Food Sovereignty just by itself a different and singular human right, which, as previously indicated, was defended.

As mentioned previously, the most developed document are the FAO voluntary guidelines, which can already be considered obsolete in certain areas. Their revision, expansion and updating would be desirable. Thus, numerous postulates defended by Food Sovereignty could then be given admittance. It is even credible that possibly a large portion of the detractors of the concept of Food Sovereignty would accept it. It is very difficult to deny that a good part of the postulates of this Sovereignty would make a more effective implementation of the progressive attainment of the right to food possible. The postulates of Food Sovereignty can definitely be useful for the reinforcement of this right. An illustrative example where this usefulness stands out is the recent petition that the

(b) Taking into account the problems of both food-importing and food-exporting countries, to ensure an equitable distribution of world food supplies in relation to need."; See also E/C.12/1999/5, 12 may 1999, The Right to adequate food (art 11), General Comments, Committee on Economic, Social and Cultural Rights.

25 Voluntary Guidelines to support the progressive realization of the right to adequate food in the context of national food security, adopted by the $127^{\text {th }}$ session of the FAO Council November 2004, Food and Agriculture Organization of the United Nations, Rome, 2005.

26 ECOSOC, The Right to Food: Report Submitted by the Special Rapporteur on the Right to Food, UN/E/CN.4/2004/10, 9 February 2004. 
Human Rights Counsel made to the Special Rapporteur for the right to food. He was asked to study whether one can equate the situation of food dependence with that of net basic food importer states. ${ }^{27}$ The persistence of this category of States, recognized by the World Trade Organization, ${ }^{28}$ clashes with the essential postulates of Food Sovereignty, which advocates the eradication of such situations. Without a doubt, understanding that this eradication is due to a violation of the right to food grants greater legal strength to this proposition.

In addition, one must keep in mind that currently the right to food stands before new challenges and threats, which were not even imagined at the time the FAO voluntary guidelines were created. There are the food crises caused by the rise in the prices of basic foods, speculation, climate change, the exclusive use of cropland to supply material for biofuels, land grabbing or the large-scale acquisition of land by foreign firms. All of those risks add up to a scenario of considerable peril for the attainment of the right to food. The right has already been undermined considerably and the perspectives for its future do not bode well at all. An immediate legal response is necessary; it must be a response that both strengthens the right to food and that seeks to consolidate its content and effectiveness. Here, naturally, the proposals defended by Food Sovereignty can be of great use and they can find their way into the content of the law.

\section{The Proposal for the Creation of an International Law About the Rural World as the Best Means for the Promotion of Food Sovereignty}

At the beginning of this paper, it was demonstrated that Food Sovereignty, exactly how its defenders conceive it, contains a wide range of content. It is composed of many diverse measures and it ultimately constitutes, indeed, a complete political program. Without a doubt, as highlighted in the previous section, a considerable part of this program can find its way into the content of the right to food. That is what this paper advocates and in this sense it would be very opportune to make efforts in this area of research.

With all due respect, Food Sovereignty is not a panacea. It is logical to deduce that as such Food Sovereignty is unable to achieve the type of holistic legal protection that the movement for the defense of Food Sovereignty advocates. At any rate, some general recognition can be obtained from certain of its proposals, but neither a detailed regulation nor its effective practical application.

It is necessary, therefore, to look for another legal solution. Food Sovereignty is so broadly articulated that it cannot be distilled into a single legal rule. It is impossible to cover so many reasons for action. Neither can it be a general principle of law. Even if principles are, in essence, general rules applicable to a multitude of situations ${ }^{29}$ the program that it is being attempted is too general. Food Sovereignty could be, as we have seen, a right that belongs to the State, to the people or to the local communities, but in

27 Human Rights Commission, Right to Food, A/HRC/RES/13/4, 14 April 2010.

28 Committee on Agriculture, G/AG/W/42/Rev.17, 30 October 2014. Implementation of the Decision on Measures Concerning the Possible Negative Effects of the Reform Programme on least Developed and Net Food-importing Developing Countries.

29 General Principles are the rationalization of rules or the combination of rules. MacCormick, N, Legal Reasoning and Legal Theory (Oxford, ed. Clarendon Press, 1978), 232. 
these cases, the content must be limited and precise. It could never be as broad as the content of the political program that is being defended.

As a consequence, one may wonder if a legal course of action exists under whose umbrella this vast political program articulated by the concept of Food Sovereignty could be covered. It appears there is. Ubi ius ibi remedium, goes the old maxim of Roman law. Accordingly, from our perspective, the solution lies in creating a new branch of international law, which amounts to obtaining a new corpus that regulates all these questions. As stated before, the program of Food Sovereignty is very broad. One wants to protect access to the natural and productive resources on the part of the communities and do away with commercial liberalization in agrarian matters. In addition, it is desirable to include agro-ecology and its practices, eliminate genetically modified crops, and carry out agrarian reforms. Likewise, protecting small-scale farmers and their rights is desired as well as obtaining control of the vegetable genetic resources, limiting any appropriation on the basis of the intellectual property rights of the multi-national corporations, and we can say, without a doubt, continue adding more postulates. There is a great variety. However, interestingly a common denominator underlies this content: the rural areas in the world.

This is the common thread that runs through the entire political program that Food Sovereignty defends and that can function as a starting point to demand the creation of International Law for the Rural World, which would be a new specific parcel within the international legal order comparable to international environmental or international law for outer space. Additionally, this proposal is very pertinent due to the forgotten status to which the rural world has been relegated by international and national politics, especially on international financial institutions such as the International Monetary Fund and the World Bank. In their plans for structural austerity widely delivered in countries in the south, there have been no attention or stimulus and development packages. ${ }^{30}$

This neglect has given rise to some very curious figures, which are authentic paradoxes. Inhabitants of countries from the global south, in their majority small-scale farmers, constitute more than seventy percent of the people who suffer from hunger in the world. ${ }^{31}$ Their ways of life are more and more precarious and their capacity for subsistence is compromised increasingly, all the while they are the food producers par excellence. They are limited to holding small areas of production, less than three hectares, and their unobstructed access to markets is hindered. As previously stated, they have lacked the support measures and rural development programs, which in turn has led to a rural exodus towards urban spaces. This is a reality at present and it acts as a stumbling block for the possibilities for development in said territories.

Furthermore, the attention given by the Official Development Aid directed at these rural zones has been up to the present extremely scarce. ${ }^{32}$ That is also something paradoxical. It would have been logical for this development aid to have made more of

30 Kydd, J and Dorward, A, "The Washington Consensus on Poor Country Agriculture: Analysis, Prescription and Institutional Gaps", 19 Development Policy Review (2001), 467.

31 See, for example, at<un.org/en/globalissues/briefingpapers/food/whatcanbedone.shtml> (accessed on 16 December 2016).

32 An exception to that was the International Conference on Agricultural Reform and Rural Development, held under the auspices of the FAO, and held in Porto Alegre, Brazil between the $7^{\text {th }}$ and $10^{\text {th }}$ of March 2006 . It advocated considerably for rural development. 
an effort and dedicated more resources to the rural environment and to the support for agricultural development since rural areas possessed more elevated indicators of poverty and hunger. This, however, has not been achieved in practice. Now it is coming to light that less than four percent of the total of said official aid has gone to agriculture and rural development in recent decades. ${ }^{33}$

On the other hand, the voices of this rural world have not been heard in the international arena. The presence of its representatives in international fora has been very limited. Up to two decades ago, in the United Nations headquaters there was only one recognized platform of agriculturalists present, the International Federation of Agricultural Producers (IFAP). That organization, moreover, is mostly composed of representatives of industrialized countries. Thus, practically speaking, there have been no communication channels with universal international organizations until its creation in February 2006 under the auspices of the IFAD (the International Fund for Agricultural Development) of the Small Scale Farmers' Forum. ${ }^{34}$

It is now that one sees that its voice possesses strength and it is reverberating in the global scene, articulating an entire political program. Without a doubt, it is worthwhile staking a claim on a greater rapprochement among the international courts to advocate the necessary prescribed legal solution. In this sense, the Coordination Committee of the International Food Security and Nutrition Civil Society Mechanism, created under the auspices of the United Nations in the Committee on World Food Security, can be of great usefulness. ${ }^{35}$ Said committee could be a suitable channel to champion this international law of the rural world. In short, one can defend the idea that the most effective legal response for attaining what the movement for the defense of Food Sovereignty proposes is to strive for the creation of a legal corpus that covers these diverse problems and necessities of the rural world. At its heart is the creation of a new branch of international law, international law for the rural world.

This is certainly not a harebrained and senseless idea. The international legal order is constantly getting more complex and it continues to expand its content, creating new separate and autonomous branches. This is a phenomenon that has come to be called the fragmentation of international law, ${ }^{36}$ which has recently been discussed by the International Law Commission of the United Nations and that has appeared as a consequence of the legal development of international law, constituting a ius specialis within general international law. Evidently, there is no hope in expecting that this creation will be rapid. The ideal situation is to hope that this new branch is composed of treaties or other obligatory legal materials and that it regulates in detail the questions that preoccupy the rural world. One must keep in mind that the processes of the creation of law are slow and difficult due to the very complexity of the international legal order.

33 See World Development Report 2008, Agriculture for Development

<siteresources.worldbank.org/INTWDR2008/Resources/WDR_00_book.pdf> (accessed on 12 November 2016).

34 Mc Keon, N, and Kalafatic, C,: Strengthening Dialogue. The Experience of the United Nations with Small Farmer Platforms and Indigenous Peoples, (New York, United Nations, 2010), 2.

35 See, Proposal for an international food security and nutrition and civil society mechanism for relations with CFS, CFS: 2010/9, Committee on World Food Security, thirty-sixth session, Rome, 11-14 and 16 October 2010, at <csm4cfs.org/> (accessed on 16 December 2016).

36 United Nations General Assembly, Fragmentation of International Law: Difficulties Derived from the Diversification and Expansion of International Law, Report from the Work Group of the Commission for International Law, A/CN.4/L.702, 18 July 2006. 
Experience has shown that before these laws of greater legal strength arrive, it is necessary to have previously proceeded through the adoption of declarations, codes of conduct or guidelines of a non-obligatory nature. States are very wary when it comes to assuming obligations.

In spite of the difficult road ahead, creating this right is the most effective manner of attaining the protection of the desired interests. Patience will be a virtue and there will have to be a search for consensus along the way in order for States to accept this right. The United Nations has begun to work in this sense through the efforts for the promotion and protection of the human rights of peasants and other people working in rural areas. ${ }^{37}$ It is desired to see the adoption of a Declaration in the coming years. This text can address many of the issues faced by the Food Sovereignty movement.

This, however, is only a first step towards a comprehensive regulation of rural problems. It, thus, appears that the main proposal must be the conclusion of a treaty with a general framework that includes development and the protection of the rural spaces and their inhabitants. This treaty could act as a guide for the politics of rural development of all the countries in the world as they confront the problems in this sphere. Already now, inroads towards the legal development of concrete questions could start to be made.

\section{Conclusions}

Food Sovereignty is being defended with increased vigour in the international arena. Most characteristically this recognition possesses a grass-roots organization, spread among large groups from civil society. Moreover, it even has begun to be accepted by some States. Up until the present day, this recognition has focused its energies predominantly on the construction of a program with an essentially political content, searching for the inclusion of the greatest number of allies to their cause. However, as of present there has not been a legal construction of this program. This labour is necessary in order for Food Sovereignty to be effective.

The first stumbling block arises from the absence of a clear and firmly fixed concept. The various definitions of Food Sovereignty are of differing content, which keeps expanding over time. This obstructs any legal specification. Nevertheless, one can advance and see who can be the owners of a possible right to Food Sovereignty. Thus, the first possible owner is the state. One could even conceive of Food Sovereignty as just another emanation of the Sovereignty that each state possesses. In addition, de lege ferenda, ideally Food Sovereignty is an inviolable rule of an obligatory nature that must be respected by everyone, and whose content is the control of food in the interior of a state, excluding any limitation to it that originates outside the state.

It also is legally viable to expand the ownership to the people. They can have the right to Food Sovereignty with the same content of the right as that given to the State. In a practical sense, giving a right to the people is the same as gaining a legal guarantee, above all as a precaution when dealing with governments. In essence, it would be a form of reinforcement in the face of deviations by the government in monitoring the compliance with Food Sovereignty.

37 UNHRC, Preliminary Study on the Advancement of the Rights of Peasants and Other People Working in Rural Areas, A/HRC/AC/6/CRP.2, 22 December 2010; UNHRC, Promotion and Protection of the Human Rights of Peasants and Other People Working in Rural Areas, A/HRC/RES/21/19, 11 October 2012. 
Likewise, it is desirable for the local communities to become owners of this Food Sovereignty. International law is already providing a legal basis for this ownership to be feasible. There are other areas in which local communities' rights are beginning to be recognized and the importance for Food Sovereignty is noteworthy, acting to protect the production of food in a concrete territory when facing outside threats. It makes the application of the law reach the most local level, in turn, it can act as a guarantee of interest.

In the same way, it also has been defended that Food Sovereignty belongs to each person individually and that it is a human right. This proposal, however, is not legally viable. If a large part of the program that defends Food Sovereignty can be considered to be part of the content of the right to food. It is necessary to broaden the content of the human right to food due to the diverse threats that hang over it.

Naturally, this consideration along with Food Sovereignty as a State's right, a people's right and that of local communities allows it to afford substantial legal protection.

But if that which is desired is to achieve a ruling as detailed and broad as the program that defends Food Sovereignty, it is worthwhile to propose the creation of a branch within international law, which could be denoted as International Law for the Rural World. Especially as the preoccupation for rural territories is the element that is present in every aspect of this broad political program that defends Food Sovereignty. 